\title{
Mary in the Apostolic Church in the Light of the Lucan Writings ${ }^{1}$
}

\author{
KRZYSZTOF MIELCAREK \\ Institute of Biblical Studies, John Paul II Catholic University of Lublin \\ e-mail: krzysztof.mielcarek@kul.pl \\ ORCID: 0000-0001-8575-7966
}

\begin{abstract}
Lucan Mariology does not present a holistic picture of Jesus' Mother, although it is without a doubt fundamentally important for the narrative of Luke-Acts. The Infancy Narrative and the three further traditions disseminated in the main body of the Lucan work (Luke 8:21;11:27-28; Acts 1:14) show that she cannot be seen only through her faith or motherhood. The author of Luke-Acts carefully composed a set of scenes in order to share with his readers a much fuller picture of Mary. As a Mother of the Lord, she is also a disciple following God's will and the teaching of her Son. In this study, the author is looking for fresh insights in the text, by applying a methodology recently presented by C. Bennema and other scholars concerning the Gospels' characters and their characterisation.
\end{abstract}

Keywords: Luke, the theology of Luke, Infancy Narrative, characterisation of Mary, Mariology of Luke

W hen starting to read the work of Luke the Evangelist, the reader cannot be sure what content he is about to encounter. In his short introduction to the Gospel, the author mentions generally "the events that have been fulfilled among us" (v. 1), and the testimony of eyewitnesses (v. 2), as well as the credible catecheses given to the audience (v. 4). A broader plan of the work can only be perceived from the vantage point of the prologue to its second volume. As Luke himself writes, the Gospel was devoted to Jesus' deeds and teachings (Acts 1:1) up to the moment of His ascension (v. 2). A short proemium of the Acts of the Apostles shows that it has been planned as a continuation of the narrative to henceforth concern the testimony of the Church borne "to the ends of the earth" (v. 8). In this way, it becomes obvious that the work of Luke was not written with the Mother of Jesus in mind, and that the motives centred on her are completely subordinated to the central goal of the Evangelist, i.e. showing the accomplishment of God's redemptive plan in Jesus the Messiah and His Church. Therefore, discovering the person of Mary in Luke-Acts requires a constant reference to

1 In the past, many studies on Luke's Mariology were published. Some of the most recent ones are worth mentioning: B.E. Reid, "An Overture to the Gospel of Luke," CThM39/6 (2012) 428-434, and J. Feník - R. Lapko, “Annunciation to Mary in Luke 1-2,” Bib 96/4 (2015) 498-524. 
the broader theological perspective of the third Evangelist. The following considerations will not so much pertain to the thematic outline drawn from systematic theology, ${ }^{2}$ but rather follow the thought of the third Evangelist.

\section{Narrative Order}

There is no doubt that the leading role of Mary in Luke-Acts is confined to the first two chapters of the Gospel. The remaining references, although not insignificant, can hardly be considered as belonging to the main plot of the story. However, Luke 1-2 leaves no doubt that the figure of the Mother of Jesus is fundamentally important for the third Evangelist and is connected to the identity of her Son in an essential way. ${ }^{3}$

For decades, experts on Luke-Acts have noticed the existence of a two-layered story in Luke 1-4, whose main characters are John the Baptist and Jesus. However, at least in the Infancy Narrative (Luke 1-2), ${ }^{4}$ both protagonists remain in the background of the events of the history of salvation when their parents come to the fore. The Hellenistic storytelling technique used by the third Evangelist, called synkrisis, skilfully juxtaposes John's ancestors: Zechariah and Elizabeth, with the figure of Jesus' Mother-Mary. In Luke's story, Joseph, the legal father of Jesus, remains almost entirely in the shadow of his wife, or blends with her into a sort of a collective character $\left(1: 7 ; 2: 4-5 .{ }^{5} 16.22-24.27 .33 .39 .41-51\right)$. In the presented list of scenes, the detailed parallelisms of the characters' statements play a significant role, as these contrastingly illustrate their attitude towards God's redemptive initiatives. There is no doubt that in the individual scenes concerning Mary, the Evangelist presented a profound picture that requires the parallel to John's parents to be taken into consideration.

2 See M. Rosik, "Mariologia," Teologia Nowego Testamentu. I. Ewangelie synoptyczne i Dzieje Apostolskie (ed. M. Rosik) (Wrocław: TUM 2008) 283-334.

3 For a more detailed comment on the scenes discussed, see J. Nolland, Luke 1:1-9:20 (WBC 35A; Dallas, TX: Word Books 1989); J.A. Fitzmyer, The Gospel according to Luke I- IX. Introduction, Translation, and Notes (AB 28A; New Haven, CT - London: Yale University Press 2008); F. Bovon, Luke 1. A Commentary on the Gospel of Luke 1:1-9:50 (Hermeneia; Minneapolis, MN: Fortress 2002); F. Mickiewicz, Ewangelia wedtug świętego Łukasza. Rozdziały 1-11 (NKB.NT 3/1; Częstochowa: Edycja Świętego Pawła 2011).

4 Henceforth: IN.

5 The census journey is the only scene in the IN in which Joseph comes to the foreground (Luke 2:5; cf. 4:22). 


\begin{tabular}{|l|l|}
\hline \multicolumn{1}{|c|}{ Zechariah and Elizabeth } & \multicolumn{1}{c|}{ Mary } \\
\hline $\begin{array}{l}\text { 1. The priest and his wife } \\
\text { 2. Righteous and orthodox }\end{array}$ & $\begin{array}{l}\text { 1. Virgin } \\
\text { 2. Married to Joseph }\end{array}$ \\
$\begin{array}{l}\text { 3. Old and sterile } \\
\text { 4. Service in the Temple (Israel's worship } \\
\text { center-Yhwh's dwelling place) }\end{array}$ & $\begin{array}{l}\text { 3. Young? } \\
\text { 4. Lives in Nazareth } \\
\text { (a place of no importance) }\end{array}$ \\
$\begin{array}{ll}\text { 5. Angelophany in the Holy Place } & \text { 5. Angelophany in a poor household } \\
\text { 7. Son will be great and so will be } & \text { 6. From fear to consideration }\end{array}$ \\
$\begin{array}{ll}\text { 8. Question and disbelief } & \text { 7. Son will be greater and so will His } \\
\text { 9. Passivity } & \text { mission }\end{array}$ \\
$\begin{array}{l}\text { 10. Elizabeth's faith } \\
\text { 8. Question and faith }\end{array}$ \\
\hline
\end{tabular}

The Evangelist speaks very highly of John's parents, as those whom God regards as righteous (Luke 1:6). However, they have no offspring and only the intervention of the Most High will change it. The news of this will reach Zechariah in the chosen people's most holy place - the House of the Lord.

The contrast with the presentation of Mary is apparent. Her meeting unfolds in a place unknown to anyone and she is devoid of any positive characteristics. The reader only learns that she is a virgin living in Nazareth and that she is married to Joseph. ${ }^{6}$ The situation changes when the initiative is taken by God's messenger, who significantly supplements the reader's knowledge. Gabriel calls Mary "the favoured one" (Greek kecharitōmenē) and assures her of God's kindness ("the Lord is with you!"). In a subsequent part of the dialogue, other extraordinary things are revealed to the reader. Mary "found favour with God" (v. 30); she will be the mother of the Messiah (v. 32-33), who, by the power of the Holy Spirit, will appear in her womb as God incarnate (v. 35). Another important contrast concerns the responses of both recipients of visitations. At first, both are accompanied by fear (tarassō, diatarassomai), a typical reaction of Biblical characters to an angel's statement. However, while Zechariah succumbs to his fear completely (v. 12), Mary overcomes it and seeks to understand Gabriel's greeting (dialogizomai - v. 29). ${ }^{7}$ The details of the angelic revelation clearly indicate that the Virgin of Nazareth will experience events incomparably greater than those of John's parents; nevertheless, it is she who believes and tries to understand her

6 The third Evangelist is well aware that his readers have never come across the name of this place and thus do not have any specific expectations of it.

7 Cf. M. Coleridge, The Birth of the Lucan Narrative. Narrative as Christology in Luke 1-2 (JSNTSup 88; Sheffield: Sheffield Academic Press 1993) 56-57. 
situation, reacting with a joyful surrender of her life to God (genoito - v. 38). The endings of the scenes juxtapose Zechariah's passivity against the dynamism of Mary's action (1:23.39).

The next scene shows the female representatives of both main characters: John and Jesus. Thanks to them, the two meet one other in the wombs of their mothers. Meeting in the mountains of Judah becomes an opportunity for the intervention of the Holy Spirit, who brings joy to the unborn John and Elizabeth into a state of prophetic elation. ${ }^{8}$ By His inspiration, Elizabeth sees her relative as "the Mother of her Lord" (v. 43) and proclaims a double blessing regarding Marys's condition and faith (v. 42.45).

The Marian theme of the first chapter of the Gospel of Luke is completed with a joyful hymn dedicated to God's greatness and goodness. Its first part also provides us with important information about the Mother of Jesus. The opening of the Magnificat proves to be a narrative bridge to the scene of the Annunciation. An unknown girl from an insignificant village makes God great (megalyno v. 46), because He has done great things for her (megala - v. 49). What occurred in Mary's life is a redemptive-historical reversal of order, a reversal also to be experienced by all Israel. The humble servant of God will henceforth be called blessed by all generations (v. 48), and her exaltation is the fulfilment of God's promises given to the patriarchs.

Luke 2 brings new information about the Mother of Jesus. The obligation to participate in the census led the young couple to Bethlehem, where Jesus was born in difficult conditions (2:7). The words of angels and shepherds convince readers that the foretold redemptive events are indeed coming true: The Lord, the Saviour, and the Messiah has come into the world (2:11), and thus His Mother is the Mother of the Messiah, Lord, and Saviour. In the last sentence of the episode, Luke points out that these events were the subject of Mary's considerations (symballō-2:19) and were carefully kept/tresured (syntēreō) by her.

In the following scenes, the Jewish identity of Jesus' family is recalled, according to which they fulfil the obligations to the Law - circumcision (2:21), and sacrifice in the Temple (2:22-24). ${ }^{9}$ On the occasion of the Magnificat canticle, Luke made his readers aware that Mary experienced her being chosen - as a member of the Jewish community of faith (1:55). The meeting with Simeon reveals a new aspect of Mary's mystery. Her Son will be the salvation of all people (2:30-32),

8 Tina Pippin ("The Politics of Meeting. Women and Power in the New Testament," That They Might Live. Power, Empowerment, and Leadership in the Church [ed. M. Downey] [New York: Crossroad 1991] 13-24) acknowledges a prophetic identity not only of Elizabeth but also of Mary, emphasising the elements of a prophetic oracle in the Magnificat canticle. Elizabeth A. Johnson sees this matter in a similar way (Truly our Sister. A Theology of Mary in the Communion of Saints [New York - London: Continuum 2003] 305-308).

9 The actions of Mary and Joseph legitimise the identity of Jesus. Only by being a member of the chosen people, incorporated into the Covenant with God, could he take up the mission of the Messiah. 
a fact that amazes her (thaumazō), and her own future will be filled with painful experiences (2:35).

The last scene of the IN, again underscores the Jewish identity of Jesus' family. Each year Joseph and Mary make a pilgrimage to Jerusalem for the Passover (2:41). The Christological character of this scene is obvious; however, it also contains valuable information about Mary, because the dignity and qualities of the Son are confronted with the condition of his parents. Mary and Joseph are not in control of the situation. First, they lose sight of Jesus, because $\mathrm{He}$ chose to stay in the Temple for a longer time; then, for three days full of suffering (odynaomai $-2: 48)^{10}$ they are trying to find Him. Jesus' climactic statement about his relationship with the Father reveals an important point: neither (not even Mary!) understands what has happened. For Jesus' rhetorical question: "Did you not know?" (2:49) presupposes a negative answer: They did not know.

The next two scenes of the main narrative of the first volume of Luke's work are of a different nature. The first, in the Marcan tradition, constitutes an intentional juxtaposition of kinship with the new kind of relationship that Jesus initiated by preaching the Kingdom. In this scene Jesus' loved ones, along with his mother, are shown as those who have no access to Him, because the new kind of bond consists in listening to the word of God and fulfilling it (Luke 8:21), and that harmonises with Mary's attitude presented earlier $(1: 29 ; 2: 19.51)$. The exclamation of an unknown woman (11:27) is of a similar sense, being a spontaneous expression of praise for the blood ties between Jesus and His Mother. However, the Master directs the attention of his listeners to the bond based upon faithful listening and observance of the Word (11:28), shared by Mary from the very beginning. That sets their bond in a new perspective.

The scenes from the Gospel are complemented by a short mention of Mary's presence among the praying Church, waiting for the gift of the Holy Spirit. The parallels between the role of the Holy Spirit in her life (Luke 1:35), the beginning of Jesus' mission by the River Jordan (Luke 3:21-22), and the inauguration of the mission of the Church (Acts 2) show that her presence is far from accidental. The strong connection of the mystery of the Eucharist and the Descent of the Holy Spirit through the place of the Cenacle is also of importance (Luke 22:7-38; Acts 1:12-2:47).

10 The intensity of this verb is emphasised by it being used elsewhere in the work (Luke 16:24-25; Acts 20:38). 


\section{Description of Characters}

All the above-presented scenes contain numerous elements highlighting the distinctive features of Mary. Analysing them in connection with the narrative context will allow us to appreciate the Mariological aspects of Lucan work. Admittedly, it may hardly be considered a systematic, orderly theology, but its respective facets should allow us to discover the content that underlies modern Mariology. ${ }^{11}$ In his excellent study on the description of New Testament characters, ${ }^{12}$ Cornelis Bennema proposed an outline that facilitates the systematic study of individual biblical characters. As a result of applying this outline to Mary in Luke-Acts, the following summary can be compiled:

\begin{tabular}{|l|l|}
\hline \multicolumn{1}{|c|}{ Mary - the Mother of Jesus } \\
\hline Presence in the story & Luke 1:26-38; 1:39-45;2:1-51; 8:19-21; 11:27-28; Acts 1:14 \\
\hline Origin & $\begin{array}{l}\text { Date and place of birth unknown, Jewish girl (virgin), resident of } \\
\text { Galilee (Nazareth) }\end{array}$ \\
\cline { 2 - 3 } & $\begin{array}{l}\text { Mary's clan living in Nazareth (?) } \\
\text { Relatives in the town of Judean mountains }\end{array}$ \\
\hline Education & Jewish social and religious education \\
\hline External goods & $\begin{array}{l}\text { The appellations } \\
\text { Narrator: The Virgin of Nazareth in Galilee able to meditate on } \\
\text { the mysteries in the presence of God, able to dialogue with God } \\
\text { Mary: Seeking understanding of God's plans (How will it happen?), } \\
\text { ready to fulfil God's will (genoito), looking for understanding of Jesus' } \\
\text { actions (Why did you do this to us?) } \\
\text { Angel/angels: Gifted with the favour, the Lord is with her, blessed } \\
\text { among women, she found favour with God, she is the mother of } \\
\text { the Messiah, Lord, and Saviour, she conceived without a man through } \\
\text { the Holy Spirit, her Son is God } \\
\text { Other characters in the story: Elizabeth: blessed is she who believed; } \\
\text { Lord's mother } \\
\text { Simeon: He will experience suffering so the inner thoughts of many } \\
\text { be revealed; } \\
\text { The Nazarenes: She and her close relatives were not renowned for } \\
\text { anything special (Luke 4:22) } \\
\text { Unknown woman: Blessed as the physical mother of Jesus } \\
\text { The Church after Passover: considers her an important figure in } \\
\text { the community }\end{array}$ \\
\hline
\end{tabular}

11 A panorama of changes occurring in Catholic Mariology from the perspective of the American Church can be found in a study by James J. Tibbetts (Historical Development of Biblical Mariology Pre- and Post-Vatican II [Dayton, OH: Marian Library Institute 1995]).

12 C. Bennema, $A$ Theory of Character (Minneapolis, MN: Fortress 2014) 111. 


\begin{tabular}{|c|c|}
\hline & $\begin{array}{l}\text { Teenage girl, married (before the ceremony of transfer } \\
\text { to her husband's house) }\end{array}$ \\
\hline & Poor girl, no information about her material possessions \\
\hline & $\begin{array}{l}\text { In Luke-Acts, she is present in Nazareth, Ein Karem, Bethlehem, } \\
\text { and Jerusalem. Indications in the Gospel of John of her-potentially } \\
\text { partial—presence during the mission of her Son (Cana) and during } \\
\text { the Passion (John 19) }\end{array}$ \\
\hline & $\begin{array}{l}\text { No profession, no special social functions, the mother and protector } \\
\text { of Jesus }\end{array}$ \\
\hline & $\begin{array}{l}\text { Attached to her own clan (Luke } 4: 22 \text {; Mark } 6: 3 \text { ) and residents } \\
\text { of Nazareth, the wife of Joseph of the house of David. } \\
\text { Present at the origins of the early Church - a member } \\
\text { of the community of believers. No information about any friends }\end{array}$ \\
\hline \multirow[t]{2}{*}{$\begin{array}{l}\text { Statements } \\
\text { and actions }\end{array}$} & $\begin{array}{l}\text { Acceptance (conception); giving birth } \\
\text { A series of actions towards Jesus during His infancy: } \\
\text { - Compliance with the Law; } \\
\text { - Jesus' education related to tensions (Luke 2:44-50) } \\
\text { - Following Jesus' teaching (Acts 1:14) } \\
\text { - Amazement, incomprehension }\end{array}$ \\
\hline & $\begin{array}{l}\text { Interaction with other characters: Gabriel, Elizabeth, Joseph, } \\
\text { shepherds, Simeon, clan members, members of the early Church }\end{array}$ \\
\hline Death & No data \\
\hline \multirow[t]{3}{*}{ Character analysis } & $\begin{array}{l}\text { Complexity - an episodic personality. Abundance of elements } \\
\text { in a narrow fragment of the story }\end{array}$ \\
\hline & $\begin{array}{l}\text { Development - from faith to more profound faith and understanding. } \\
\text { A process marked by fear, amazement, and suffering }\end{array}$ \\
\hline & $\begin{array}{l}\text { Inner Life: } \\
\text { - self-control } \\
\text { - reflectiveness } \\
\text { - understanding } \\
\text { - faith } \\
\text { - trust } \\
\text { - obedience } \\
\text { - memory } \\
\text { - readiness to grow mature } \\
\text { - fear } \\
\text { - incomprehension } \\
\text { - amazement } \\
\text { - inner struggle/suffering }\end{array}$ \\
\hline $\begin{array}{l}\text { Character } \\
\text { classification }\end{array}$ & $\begin{array}{l}\text { The degree of description } \\
\text { Brief, but rich character description. A series of external and internal } \\
\text { elements. Absent in most plot lines of Luke's work }\end{array}$ \\
\hline
\end{tabular}




\begin{tabular}{|l|l|}
\hline Character evaluation & $\begin{array}{l}\text { From the point of view of the author } \\
\text { and of the protagonist-Jesus: } \\
\text { - Adequate attitude in the short and long term perspective } \\
\text { of the narrative } \\
- \text { A dynamic, tried and tested way of faith (fear, doubt, amazement, } \\
\text { suffering) }\end{array}$ \\
\hline & $\begin{array}{l}\text { Regarding her role in the plot: } \\
\text { She enables the realisation of God's plans; gives life to Jesus; meets } \\
\text { all the requirements of the Law, by legalising Jesus as the Messiah } \\
\text { of Israel; zealously accepts the will of God; she listens attentively to } \\
\text { God's message sent to her through angels, people, and circumstances; } \\
\text { she lives out her life in the community of Jesus' disciples }\end{array}$ \\
\hline The meaning of \\
the character & $\begin{array}{l}\text { Distinctive value of the character: } \\
- \text { Gifted by God } \\
\text { - Invited to participate in his plans - motherhood } \\
- \text { The one who believed } \\
\text { - A disciple/servant of the Lord }\end{array}$ \\
\hline
\end{tabular}

\section{Mary's Identity as a Consequence of God's Actions}

Luke's descriptions in the IN clearly stresses God's initiative towards Mary, primarily emphasised by the angelic message in the Annunciation scene. Giving special favours to Mary constitutes its first element; the second is the announcement of the extraordinary honour that God will grant to her - the motherhood of the Messiah, the Son of God.

\subsection{Endowed with Grace}

Through Gabriel's message, the scene of the Annunciation constructs the image of Mary as steeped in grace. Luke uses the term kecharitomene, seldom occurring in the Bible, usually rendered in many European languages in the Catholic translations as "full of grace" (Luke 1:28) ${ }_{13}^{13}$ after the Vulgate (Latin: gratia plena). In addition to this term, the angel assures the future Mother of the Messiah that she is the object of special kindness on the part of God, which is expressed in the Old Testament phrase "to find favour with God" (1:30). ${ }^{14}$ The Greek kecharitomene was not faithfully transmitted in all early Christian translations. The transla-

13 Most English translations are closer to the Greek original and render the phrase as "favoured one."

14 It can be found in many places in the Old Testament; see, for instance: Gen 6:8. 
tions strictly adhering to the verbal perfect form of charitoo retain its participial character and translate this word into Latin as gratificata (codex Palatinus and q), but admittedly this version is rather infrequent in the Latin translations by the Church Fathers.

The form kecharitomene occurs only once in the Septuagint and in the New Testament. The Book of Sirach refers it to a man who combines good gifts and a good word (18:17). The verb charitoo itself can also be found outside of Luke's work in Eph 1:6. In this case, however, the active form is used and refers to God granting grace to believers in Christ. ${ }^{15}$ The passive participle of the perfectum tense pertains to a particular accomplished activity, the effects of which cover the present and the future. ${ }^{16}$ Endowing Mary with grace should therefore be pondered in terms of a permanent change that had occurred prior to the angelophany described by Luke. In other words, God intervened in the life of Mary beforehand, and the scene of the Annunciation continues the sequence of redemptive events. ${ }^{17}$

The scenes with Zechariah and Mary reveal an important specific difference in the attitude of the angel. Mary's angelophany is welcomed by a call to joy (chaire) $)^{18}$ and an assurance of God's kindness ("The Lord is with you!") accompanied by the word kecharitōmene todescribe her (1:28). The name replaced with a participle brings to mind the scene of Gideon's calling (Judg 6:11-24). ${ }^{19}$ As in the case of Luke's work, the figure meeting God is an insignificant man from a poor village. Greetings are similar: "The Lord is with you!," and instead of the recipient's name: "mighty warrior." Both scenes also contain a cohesive angelic message (Judg 6:14; cf. Luke 1:30-33), doubts of the recipients (Judg 6:15; cf. Luke 1:34) and an appropriate explanation (Judg 6:16-24; cf. Luke 1:35-37). Each mentions God's help and a sign of strengthening the recipient's faith (Judg 6:16-17; Luke 1:35-37).

Mary's new state of being endowedwith grace is expressed in her personal prayer. When singing the Magnificat canticle, she is referring to the great things (megala) the Lord has done to her (Luke 1:49), which lead her to make God great (magalyno-1:46). She considers her exaltation to be one more element of Sav-

15 Cf. the meaning of the verbs with the ending -oō, e.g.: leukoo - "to whiten"; doulō - "to enslave"; R. Popowski, Wielki słownik grecko-polski Nowego Testamentu (Warszawa: Vocatio 1995) 652.

16 M. Zerwick, Biblical Greek Illustrated by Examples (Rome: PIB 1963) 96.

17 The perfectum form, however, does not allow this moment to be moved too far into the past. Joseph A. Fitzmyer also sees it that way (The Gospel according to Luke I-IX, 345-346). Luke focuses on the moment of the Annunciation, and the Church Fathers broaden his understanding.

18 Greek chaire was the standard formula for a greeting. In contemporary Polish its counterpart is: "Witaj!" (Hail!).

19 Other descriptions of vocations also adopt a similar three-element structure (Jer 1:4-8; Isa 6, Ezek 1-3): after the introduction (v. 4) there are: (1) choosing the one and entrusting them with the mission (vv. 5-6), then (2) the objections of the chosen one (v. 7) and finally (3) the assurance of God's assistance (v. 8); cf. also Exod 3-4; Judg 6:11-17; 1 Sam 9:17-10:7. 
iour's plan, who performed great signs in the past and is now completing his plan by fulfilling the promises made to the patriarchs (1:55).

The angel's message is complemented by Gabriel's assurance that Mary has found favour with God. The form of the aorist used by the Evangelist indicates a single past event. As in the images from the Old Testament, this formula meant God's special kindness (Gen 6:8; 18:3; 19:19; Exod 33:12; 2 Sam 15:25) and was used in reference to the key figures in the history of salvation, so in relation to the Mother of Jesus, it places her among the greatest representatives of humanity who participated in the accomplishment of God's plans.

\subsection{Invited to Participate in God's Plans}

The entire message carried by the angel clearly emphasises the initiative on the part of God, who had endowed Mary with grace and now invites her to participate in his redemptive plans. She was chosen to become a mother. She will conceive and give birth to a son, Jesus (Luke 1:31) ${ }^{20}$ who will be great (megas), ${ }^{21}$ because he will fulfil the promises made to David (2 Sam 7:12-14). Mary will therefore be the mother of the Messiah who will enjoy a special relationship with God - "he will be called the Son of the Most High" (Luke 1:32).

Mary's motherhood in relation to the messianic dignity of her Son is the most obvious fulfilment of the expectations of the followers of Judaism. The fulfilled prophecies, which she herself mentions in the Magnificat canticle, will inaugurate the eschatological era of Israel's restoration and the final crackdown on its enemies. ${ }^{22}$ The future Messiah will be born in Bethlehem (Mic 5:1-2), a fact secured by Luke with a census (Luke 2:1-4). It is also known from the Annunciation that the oracle of the prophet Nathan will be fulfilled (1 Sam 7:12-14). However, Mary's question in the following verse (1:34) provokes a deeper revelation of the mystery: her descendant will be placed in her womb without the participation of a man and with the special assistance of the Holy Spirit (1:35). In this context, the term Son of God cannot be treated only as an Old Testament reference to God's elect (Exod 4:22; Hos 11:1; Jer 31:9; Ps 82:6). The situation of Jesus coming into the world is unique and thus His Mother is truly the Mother of the Son of

20 Hansjürgen Verwehen (“Mariologie als Befreiung. Lk 1:26-45.56 im Kontext," ZKTh 105/2 [1983] 173) sees here an allusion to the scene of the angel with Hagar (Gen 16:11).

21 This motive indicates that the great "things" (megala) for which Mary makes God great do not have to refer only to the redemptive events in general, but also to Jesus himself.

22 The juxtaposition of one's own fate and the fate of the oppressed and the poor, whom God will raise to the fullness, can also be treated as an echo of Gabriel's kecharitomenē, as it reminds us of the impoverished origin of Mary, who will ultimately be called blessed by all generations; see Johnson, Truly Our Sister, 266. 
God. Luke's work does not use the term Mother of God (Greek Theotokos), but Gabriel's message certainly provides a strong foundation for this title.

Such reasoning is supported by a closer analysis of the description relating to the action of the Holy Spirit towards the future Mother of Jesus. The Gospel text speaks of "coming upon" (Greek eperchomai) and "covering" (Greek episki$a z \bar{o}$ ), thus referring readers to the Old Testament idea of Providence (Ps 90:4; LXX) and the journey of the Israelites through the desert (Exod 40:35). There, the cloud of glory of the God of Israe ${ }^{23}$ covered the tent of meeting, filling it with His presence. In the third Gospel, the very same presence of God created human nature in Mary's womb. Mary-having been prepared (kecharitōmenē) - accepted the God-man in her womb, becoming the Tabernacle of the New Covenant.

The Visitation scene seems to go in the same direction. There, the meeting also takes place with the active presence of the Holy Spirit, who inspires Elizabeth to call Mary "the Mother of my Lord" (Luke 1:43). The third Evangelist thus announces the glory of Jesus, which will be revealed after the completion of His mission (Luke 24:34; cf. Acts 2:36), when the Risen will reveal himself as Kyrios in the full sense of the word. The angelic message that the Saviour, the Messiah, and the Lord was born in Bethlehem is of a similarly proleptic character (Kyrios - Luke 2:11). The angels therefore confirm what Elizabeth had said earlier by the inspiration of the Holy Spirit. Mary is truly the Mother of the Lord.

For obvious reasons, Luke's story emphasises the miraculous motherhood of Mary. However, the scene of the Annunciation is introduced by the information about Mary's virginity (parthenos), at the same time connecting it with the message about her being Joseph's wife (Luke 1:27). In the course of the dialogue with Gabriel, it becomes clear that the announced motherhood will not remove her virginity, because the promised offspring will live in her womb thanks to God's intervention (1:35). Mariological reflection from the first centuries of Christianity made virginitas an essential dimension of the identity of the Mother of Jesus Christ. However, Luke's reflection does not go beyond the protection of the identity of the future Messiah. That is why the most obvious dimension of Mary's virginity in the work of the third Evangelist is her condition until the birth of Jesus. ${ }^{24}$ The reader of the work should know that Jesus does not have an earthly father in the biological sense, because Joseph is his father de iure, but not

23 Johnson, Truly Our Sister, 252.

24 Some post-Reformation churches reject the virgin state of Mary after the birth of Jesus, pointing to the mentions of His brothers and sisters (Matt 13:55-56). Catholic exegesis proposes to understand this tradition in the sense of a wider family or clan, meaning that the siblings in question would be $d e$ facto cousins. On the other hand, the author of the Protoevangelium of James tries to secure the truth about the virginity of Mary - he informs us about the advanced age of Joseph, who was to become espoused to Mary as a widower, having had his own children (Prot Jas 9:1-3). 
de facto (hōs enomizeto - Luke 3:23). Thereby, Mary's motherhood is miraculously marked by her virgin condition.

Proponents of extending the foundations of Mary's virginity in the biblical tradition point to the question of Mary they find crucial in the Annunciation scene, showing her lack of sexual contact with a man (Luke 1:34). ${ }^{25}$ The meaning of this question proves relatively difficult to explain. Carmelo Pellegrino ${ }^{26}$ decided to find a solution using the narrative method. Noting the importance of the texts referring to the figure of Mary in the later section of the work (Luke 8:19-21 and 11:27-28), he emphasises that they deal with the topic of blood ties in the context of the community of Jesus' relatives. There, Jesus points to a new logic of closeness, which, according to His Gospel, consists in listening faithfully to the word and keeping it. The reader is thus forced to recall Mary's demeanour displayed in the IN. Her attitude was that of being totally and unconditionally entrusted to God and of carefully committing to memory His initiatives, all the way to being present among the disciples awaiting the Father's promise (Acts 1:14). It is a sign that Mary accepted the logic of the Gospel, taking up spiritual fertility instead of a biological one.

\section{Mary's Response to God's Action}

Luke's descriptions of the Mother of Jesus cannot be reduced to the dimension of God's initiatives. The Evangelist sees the priority of His favour and His salvation plans as beyond doubt. However, Mary's activity in dialogue with God is strongly highlighted as well. In the narrative scheme presented in the opening fragment of the article, two largely overlapping dimensions of this activity were discovered. The first one is best summed up by Elizabeth's words spoken by the inspiration of the Holy Spirit in the scene of the visitation: "Blessed is she who believed" (Luke 1:45). Mary is a woman of faith, a person who trustingly accepts God's offer. The act of joyful and energetic trust in the presence of the angel Gabriel did not finish Mary's journey of faith. Its successive stages were outlined in the following scenes of the IN, up to the mention in Acts 1:14. It is so rich that it can be

25 This is the common understanding of Mary's question, as legally she is already married; see Fitzmyer, The Gospel according to Luke I-IX, 52-54.

26 C. Pellegrino, Maria di Nazaret, Profezia del Regno. Un approccio narrativo a Lc 1.34 (Analecta biblica. Dissertationes 206; Roma: Gregorian \& Biblical Press 2014). Hereby, I would like to express my gratitude to Rev. Prof. Adam Kubiś, who not only drew my attention to this monograph, but also provided his own material from the paper he was writing on this subject. There, the reader will find a broad presentation of the scholarly discussion on Luke 1:34. 
considered a kind of school of Christ's disciple ${ }^{27}$ through which the Evangelist invites his readers to follow Mary's experiences.

\subsection{Blessed is She Who Believed}

In the Annunciation, the noun "faith" and the verb "believe" are not used even once. The parallel to the annunciation to Zechariah and his disbelief presented there create tension in the reader as to the outcome of the angel's visit in Nazareth. However, the whole scene ends with Mary's enthusiastic consent to participate in God's plans (genoito - Luke 1:38) ${ }^{28}$ What was negatively confirmed in the case of Zechariah is transferred to the next scene in the case of Mary, where the narrator informs through the mouth of Elizabeth, driven by the Holy Spirit, that Mary believed and therefore is blessed (Luke 1:45).

The obedience of faith in the Annunciation scene was expressed by a simple formula: "Here am I, the servant of the Lord," complemented with the wish that the words of the Lord be fulfilled. The term "servant" (Greek doulē) appears once again in the Magnificat, where Mary additionally speaks about her "humility" (tapeinōsis - cf. Acts 8:33). In this manner, Luke associates the Magnificat with Isa 58:3, where the humility of the Lord's Servant is mentioned. A metaphorical meaning is also possible, indicating the awareness of God's transcendence and of her own fragility, for Mary belongs to the "poor of the Lord," who are under God's special protection. ${ }^{29}$

\subsection{Mary in the School of God and His Son}

Accepting God's message and believing in its fulfilment, shown in the scene of the Annunciation, are not a one-time act that indicates some static feature of the character described. Luke, describing the attitude of Mary, uses verbs that allow the reader to discover that she is a model example of a disciple: "listening and pondering" (dialogizo-Luke 1:29), "memory" (syntēreo-2:19), and "inner reflection" (symballō-2:19).

27 E.A. Johnson sees it in a similar way (Truly Our Sister, 247).

28 E.A. Johnson (Truly Our Sister, 256-257) sees Mary's statement as a parallel to Isaiah's consent in the scene of his calling (or other prophets' calling), and attributes to Luke the intention of portraying the village girl as a prophetess.

29 Bovon, Luke 1:61. In Mary's hymn, the feminist circles find — above all — a paradigmatic scene concerning all the oppressed and marginalised; see J.D. Schaberg, "Luke," Women's Bible Commentary, 3 ed. (ed. C.A. Newsom - S.H. Ringe) (Louisville, KY: Westminster Knox 2012) 284. 
Although the verb akouō does not appear in reference to Mary, her listening attitude was presented using the showing technique. ${ }^{30}$ Luke introduces Mary's attitude of listening using a broader context. Only the further activity of the future Mother of Jesus is shown by specific verbs (telling). This oblique information will later become the basis for a rhetorical appeal to the reader in the main part of the Gospel narrative. Mark's tradition about the new family of Jesus "who hears the word of God and does it" (Luke 8:21) acquires a new Mariological aspect. The reader is called to count Mary as one of Jesus' relatives not because of the blood ties, but because of her attitude of listening faithfully to the word (cf. Luke 11:27-28). The verbs syntēreō/diatēreō/fylassō ("to keep"/"to guard") complement this picture.

The two consecutive verbs expressing the idea of discussing the redemptive events only deepen the previous intuitions about Mary engaged in the dialogue with God. In this way, Luke further emphasises the human nature of the Virgin of Nazareth, who does not bear the divine ability to understand all things, but, thanks to faith and the readiness of the heart, is able to enter the path of gradual discovery (Luke $1: 29 ; 2: 19$ ). She is fully involved in the events in which she participates and wants to bear their weight and significance. The fact that God does not reveal everything to her from the very beginning ${ }^{31}$ is indicated by her very natural amazement (thaumazō - Luke 2:33) in face of Simeon's address about Jesus, as well as his announcement of the experiences she will have to suffer in the future. Simeon's prophecy mentions a sword (Greek romfaia) to pierce her soul,,$^{32}$ and thus foreshadows her difficult experiences.

The image of Mary in the school of God and His Son was not abandoned at this dramatic moment. The Evangelist completes it with the presence of the Mother of the Lord in the community of the Church in Jerusalem, immersed in prayer, awaiting the Father's promise to begin the mission of witnesses to the Risen One (Acts 1:14). There is no doubt that this is a clear signal to the reader that Mary has achieved her goal of discipleship. Together with the apostles, she took up the teaching of her Son and in faith she moved towards its final fulfilment. ${ }^{33}$ Mary, praying with the Church after the Passover, complements Luke's Mariolo-

30 On the subject of telling \& showing, see M.H. Abrams, A Glossary of Literary Terms, 4 ed. (New York: Holt, Rinehart \& Winston 1981) 20.

31 In the past, this subject was also taken up by American biblical scholars as part of ecumenical agreements, see R.E. Brown et al. (eds.), Mary in the New Testament (Mahwah, NJ: Paulist Press 1987) $150-151$.

32 The term "soul" (Greek psyche) appeared earlier in connection with joy and praise (Luke 1:46-47).

33 Catholic tradition, especially the iconography, tends to limit the representation at the Pentecost to the circle of the apostles and Mary. However, Luke, by exposing the presence of Mary and the Twelve, suggests a much wider presence of the disciples, including women and Jesus' brothers. Even the specific number of participants in the assembly is mentioned, that of about one hundred and twenty (Acts 1:14-15). 
gy and recalls scenes from the IN, where the Mother of Jesus begins her way of the individual (Luke 1:46-55) and collective (Luke 2:22-39) prayer.

$$
* * *
$$

The panorama of biblical texts and their interpretations presented above is certainly far from complete. The narrative approach to Luke's texts allowed us, however, to identify the main theological motifs that make up the message of the third Evangelist. Based on the presented analyses, it can be concluded that the image of Mary proposed by Luke boils down to two basic dimensions: God's gift expressed in the spiritual name of Mary - kecharitomēne which resulted in her direct participation in the history of salvation through motherhood, and Mary's active response expressed through her consistent faith, which in time became the path of Christ's disciple. These two aspects are an essential part of the basis for biblical Mariology on which the faith of the early Church and successive generations of Christians was founded.

\section{Bibliography}

Abrams, M.H., A Glossary of Literary Terms, 4 ed. (New York: Holt, Rinehart \& Winston 1981).

Bennema, C., A Theory of Character (Minneapolis, MN: Fortress 2014).

Bovon, F., Luke 1. A Commentary on the Gospel of Luke 1:1-9:50 (Hermeneia; Minneapolis, MN: Fortress 2002).

Brown, R.E. et al. (eds.), Mary in the New Testament (Mahwah, NJ: Paulist Press 1987).

Coleridge, M., The Birth of the Lucan Narrative. Narrative as Christology in Luke 1-2 (Journal for the Study of the New Testament Supplement Series 88; Sheffield: Sheffield Academic Press 1993).

Feník, J. - Lapko, R., “Annuciation to Mary in Luke 1-2,” Biblica 96/4 (2015) 498-524.

Fitzmyer, J.A., The Gospel according to Luke I-IX. Introduction, Translation, and Notes (AB 28A;

New Haven, CT - London: Yale University Press 2008).

Johnson, E.A., Truly Our Sister. A Theology of Mary in the Communion of Saints (New York - London: Continuum 2003).

Mickiewicz, F., Ewangelia wedtug świętego Lukasza. Rozdziaty 1-11 (Nowy Komentarz Biblijny.

Nowy Testament 3/1; Częstochowa: Edycja Świętego Pawła 2011).

Nolland, J., Luke 1:1-9:20 (Word Biblical Commentary 35A; Dallas, TX: Word Books 1989).

Pellegrino, C., Maria di Nazaret, Profezia del Regno. Un approccio narrativo a Lc 1.34 (Analecta biblica. Dissertationes 206; Roma: Gregorian \& Biblical Press 2014).

Pippin, T., "The Politics of Meeting. Women and Power in the New Testament," That They Might

Live. Power, Empowerment, and Leadership in the Church (ed. M. Downey) (New York: Crossroad 1991) 13-24.

Popowski, R., Wielki stownik grecko-polski Nowego Testamentu (Warszawa: Vocatio 1995). 
Reid, B.E., "An Overture to the Gospel of Luke," Currents in Theology and Mission 39/6 (2012) 428-434.

Rosik, M., "Mariologia,” Teologia Nowego Testamentu. I. Ewangelie synoptyczne i Dzieje Apostolskie (ed. M. Rosik) (Wrocław: TUM 2008) 283-334.

Schaberg, J.D, “Luke," Women's Bible Commentary, 3 ed. (ed. C.A. Newsom - S.H. Ringe) (Louisville, KY: Westminster John Knox 2012).

Starowieyski, M., "Kulturotwórcza rola apokryfów," Idee chrześcijańskie w życiu Europejczyka (eds. A. Ceglińska - Z. Staszewska) (Łódź: Archidiecezjalne Wydawnictwo Łódzkie 2001) I, 63-76.

Tibbetts, J.J., Historical Development of Biblical Mariology Pre- and Post-Vatican II (Dayton, OH: Marian Library Institute 1995).

Verwehen, H., "Mariologie als Befreiung. Lk 1,26-45.56 im Kontext," Zeitschrift für katholische Theologie 105/2 (1983) 168-183.

Zerwick, M., Biblical Greek Illustrated by Examples (Rome: PIB 1963). 